JURNAL EINSTEIN
Jurnal Hasil Penelitian Bindang Fisika
$\begin{gathered}\text { Available online http://jurnal.unimed.ac.id/2012/index.php/inpafi } \\ \text { e-issn: } 2407-747 x, p-i s s n 2338-1981\end{gathered}$

\title{
PENGARUH WAKTU TAHAN KALSINASI FILM TIPIS ZNO TERHADAP EFISIENSI DSSC (DYE SENSITIZIED SOLAR CELL) YANG MENGGUNAKAN DYE DARI BUAH NAGA MERAH
}

\author{
Sri Karina Pinem dan Nurdin Siregar \\ Jurusan Fisika, Fakultas Matematika dan Ilmu Pengetahuan Alam, Universitas Negeri Medan, \\ Indonesia \\ srikarinapinem@gmail.com \\ Diterima Februari 2018; Disetujui Februari 2018; Dipublikasikan Februari 2018
}

\begin{abstract}
ABSTRAK
Salah satu energi alternatif yang mempunyai potensi sumber energi yang sangat besar untuk mencegah terjadinya krisis energi namun sering kali terabaikan adalah sinar matahari. Oleh karena itu, penelitian ini dilakukan untuk menghasilkan prototype dalam mengkonversi energi cahaya matahari menjadi energi listrik. Penelitian mengenai dye sensitized solar cell dilakukan dengan dye dari ekstrak buah naga merah sebagai sumber energi alternatif dari tenaga surya. Dye sensitized solar cell (DSSC) dibuat dengan menggunakan semikonduktor $\mathrm{ZnO}$ yang dilapiskan pada kaca konduktif Fluorine Doped Tin Oxide (FTO) dan dikalsinasi dengan variasi waktu tahan 15 menit, 30 menit dan 45 menit dengan temperatur tetap yaitu $550^{\circ} \mathrm{C}$. Lapisan $\mathrm{ZnO}$ pada substrat dikarakterisasi dengan menggunakan SEM dan XRD. Densitas arus dan voltase maksimum diperoleh pada variasi waktu tahan 30 menit dengan temperatur $550^{\circ} \mathrm{C}$ yaitu sebesar $0,611 \mathrm{~mA} / \mathrm{cm} 2$ dan $1114 \mathrm{mV}$. Efisiensi maksimum yang diperoleh sebesar $0,146 \%$.
\end{abstract}

Kata Kunci : Dye Sensitized Solar Cell, Temperatur Kalsinasi, Waktu Tahan Kalsinasi, Buah Naga

Merah,

$\mathrm{Zn}$

\section{PENDAHULUAN}

Perkembangan era globalisasi saat ini berdampak pada kebutuhan konsumsi energi listrik yang semakin meningkat. Sangat diperlukan sumber energi alternatif yang dapat didaur ulang untuk memenuhi kebutuhan listrik saat ini salah satunya menggunakan energi sinar matahari yang mempunyai potensi sumber energi yang sangat besar namun sering kali terabaikan. Dye Sensitized Solar Cell atau yang sering disingkat dengan DSSC merupakan salah satu kandidat potensial sel surya generasi mendatang, hal ini dikarenakan tidak memerlukan material dengan kemurnian tinggi sehingga biaya proses produksinya yang relatif rendah. Berbeda dengan sel surya konvensional dimana semua proses melibatkan material silikon itu sendiri, pada DSSC absorbsi cahaya dan separasi muatan listrik terjadi pada proses yang terpisah. Absorbsi cahaya dilakukan oleh molekul dye, dan separasi muatan oleh inorganik semikonduktor nanokristal yang mempunyai band gap lebar. Penggunaan semikonduktor dengan band gap lebar akan memperbanyak elektron yang mengalir dari pita konduksi ke pita valensi, karena dengan band gap yang lebar tersebut akan membuat ruang reaksi fotokatalis dan absorpsi oleh dye akan menjadi lebih banyak atau dengan kata lain spektrum absorbsi menjadi lebih lebar. 
Pada penelitian kali ini untuk meningkatkan efisiensi DSSC (Dye Sensitized Solar Cell) menggunakan dye dari buah naga super merah, sudah diteliti bahwa daging dalam buah naga super merah memiliki warna ungu yg absorbansinya $3,300 \mathrm{~nm}$ sehingga dapat digunakan untuk dijadikan dye dalam efisiensi DSSC (Dye Sensitized Solar Cell). Selain lebih mudah diperoleh, bahan-bahan yang digunakan pada penelitian ini memiliki biaya yang jauh lebih ekonomis. Proses pembuatan DSSC yang digunakan untuk penelitian ini juga sederhana. Jika dilihat dari efisiensi memang efisiensi DSSC dari hasil penelitian sebelumnya yang menggunakan ekstrak dari bahan-bahan alami masih cukup rendah. Namun DSSC ini memiliki potensi untuk didaur ulang menjadi lebih efisien. Dan akan dibuat prototipe Dye Sesnsitized Solar Cell dengan menggunakan $\mathrm{ZnO}$ yang dibuat dari precursor Zinc Acetat Dehydrete $\left\{\mathrm{Zn}\left(\mathrm{CH}_{3} \mathrm{COOH}\right) \cdot 2 \mathrm{H}_{2} \mathrm{O}\right\}$. Sedangkan untuk elektrolit cairnya digunakan campuran Pottasium Iodide dan Iodineyang diaduk bersama dengan larutan acetonitrile yang akan dikaji kelayakan uji listrik dari Dye Sensitized Solar Cell dan divariasikan pada waktu kalsinasi pada pasta ZnO. Harapannya, dihasilkan prototipe DSSC dengan nilai efisiensi lebih tinggi dan lebih baik dari penelitian sebelumnya.

\section{METODE PENLITIAN}

Gambar 2.3 menunjukkan skema kerja dari DSSC, pada dasarnya merupakanreaksi dari transfer elektron meliputi :

1. Terjadinya eksitasi elektron pada molekul dye akibat absorbsi foton. Elektron tereksitasi dari ground state (D) ke excited state $\left(\mathrm{D}^{*}\right)$

$$
\mathrm{D}+\mathrm{e}^{-} \longrightarrow \mathrm{D}^{*}
$$

2. Kemudian setelah dari excited state, elektron langsung terinjeksi menuju conduction band $\left(\mathrm{E}_{\mathrm{CB}}\right)$ titania sehingga molekul dye teroksidasi $\left(D^{*}\right)$. Dengan adanya donor elektron oleh elektrolit ( $\left.\mathrm{I}^{-}\right)$ maka molekul dyekembali ke keadaan awalnya (ground state) dan mencegah penangkapan kembali elektron oleh dye yang teroksidasi.

$$
2 \mathrm{D}^{+}+3 \mathrm{e}^{-} \longrightarrow \mathrm{I}^{3-}+2 \mathrm{D}
$$

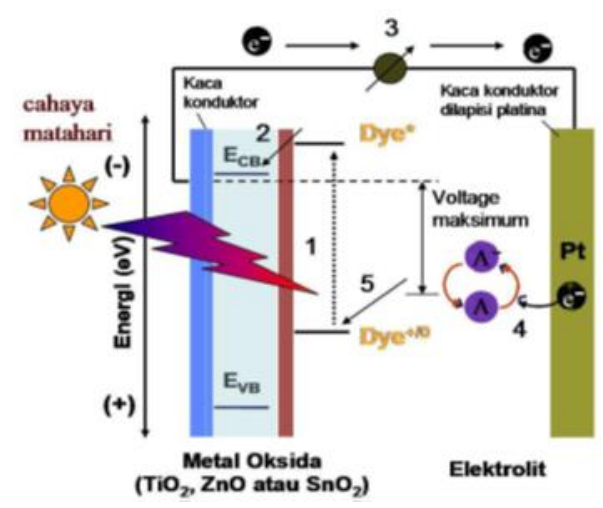

Gambar 1. Prinsip Kerja Sel Surya

Fotoelektrokimia

(Sumber : Setiawan dkk, 2015)

3. Elektron akan mengalir menuju elektrode CE (Counter-Elektrode) melalui rangkaian eksternal setelah mencapai elektrode WE (Working Electrode).

4. Adanya katalis pada elektroda CE (Counter-Elektrode), elektron diterima oleh elektrolit sehingga hole yang terbentuk pada elektrolit $\left(\mathrm{I}_{3}{ }^{-}\right)$, akibat donor elektron pada proses sebelumnya, berkombinasidengan elektron membentuk iodide ( $\left.\mathrm{I}^{-}\right)$.

$$
\mathrm{I}^{-}+2 \mathrm{e}^{-} \longrightarrow 3 \mathrm{I}^{-}
$$

5. Iodide ini digunakan untuk mendonor elektron kepada dye yang teroksidasi, sehingga terbentuk suatu silklus tansport elektron, kemudian dari siklus ini, secara langsung akan terjadi konversi cahaya matahari menjadi listrik.

\section{HASIL DAN PEMBAHASAN}

\section{Hasil Penelitian}

\section{Hasil Preparasi Film Tipis ZnO Terhadap Dengan} Metode Sol-gel Spin Coating

Film tipis $\mathrm{ZnO}$ dengan variasi waktu tahan telah berhasil disintesis dengan metode sol-gel spin coating. Proses pencampuran Zinc acetat dehydrate sebagai prekursor yang dilarutkan dalam pelarut isopropanol dan distabilkan dengan diethanolamine (DEA) dengan menggunakan teknik refluks yang bertujuan untuk mengontrol laju reaksi serta 
mengisolasi proses sintesis dari kelembaban udara luar. Proses pembuatan sol-gel dengan metode sol-gel dengan pencampuran menggunakan teknik refluks seperti ditunjukkan pada Gambar 2.

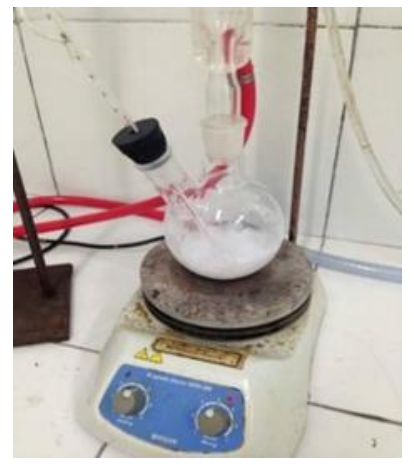

Gambar 2. Pembuatan Sol-gel Dengan

Metode Sol-gel dengan pencampuran teknik refluks

Pelapisan dilakukan pada kaca FTO yang bertujuan untuk mendapatkan lapisan yang baik, rata dan homogen dengan teknik spincoating.

Proses pemanasan lapisan berturut-turut pada suhu $100^{\circ} \mathrm{C}$ (kalsinasi) untuk pre-heating $300^{\circ} \mathrm{C}$ selama 5 jam dengan waktu tahan 10 menit. Sampel film tipis dengan suhu preheating $300^{\circ} \mathrm{C}$ berupa gel bening yang dideposisi menjadi berwarna kekuning-kuningan seperti Gambar 3.

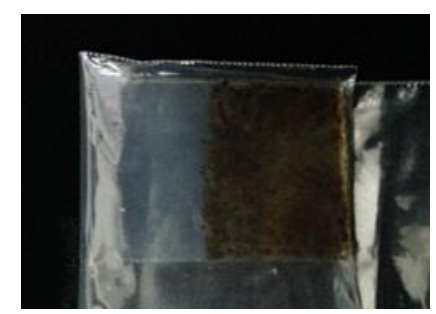

Gambar 3. Sampel Film Tipis ZnO dengan suhu pre-heating $300^{\circ} \mathrm{C}$

Kemudian sampel film tipis tersebut di post-heating pada suhu $550^{\circ} \mathrm{C}$ dengan variasi waktu tahan 15 menit, 30 menit dan 45 menit. Sampel film tipis $\mathrm{ZnO}$ dengan suhu post-heating $550^{\circ} \mathrm{C}$ waktu tahan 30 menit menjadi serbuk yang berwarna keputih-putihan yang melekat pada kaca seperti pada gambar 4 .

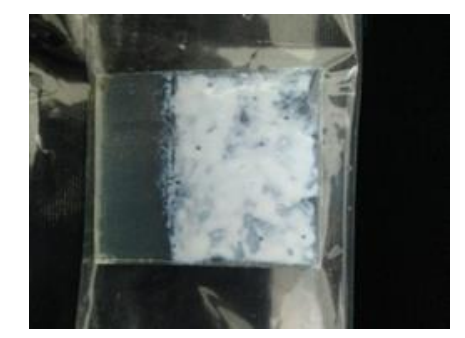

Gambar 4. Sampel Film Tipis $\mathrm{ZnO}$ dengan suhu post-heating $550^{\circ} \mathrm{C}$

$\mathrm{ZnO}$ terjadi sebagai bubuk putih seperti Gambar 4.4. umumnya dikenal sebagai seng putih zincite mineral. Mineral biasanya beris sejumlah unsur mangan dan lainnya dan kuning ke warna merah. Oksida seng kristal termokromat, berubah dari putih ke bening ketika dipanaskan dan di udara beralih keputih pada pendinginan. Perubahan warna seperti ini terjadi karena perubahan temperatur, dikenal sebagai sifat termokromik. Perubahan warna seng oksida tersebut karena pemanasan, beberapa atom oksigen hilang dari kisi kristalnya sehingga meninggalkan kisi kristal dalam keadaan kelebihan muatan negatif dan ini menghasilkan warna yang berbeda, kelebihan muatan negatif (elektron) dapat dipindahkan melalui kisi kristal dengan perbedaan potensial. Jadi, seng oksida ini bersifat sebagai semikonduktor. Pada pendinginan, atom-atom oksigen yang keluar dari kisi pada pemanasan tersebut kembali lagi ke posisi semula sehingga diperoleh warna semula (Nurdin, 2015).

\section{Struktur Dan Ukuran Kristal Film Tipis ZnO Struktur Kristal Film Tipis ZnO}

Spektrum difraksi $X$-ray Diffraction (XRD) sampel film tipis $\mathrm{ZnO}$ hasil sintesis dengan metode sol-gel spin coating dengan pencampuran teknik refluks untuk suhu preheating $300^{\circ} \mathrm{C}$, post-heating $550^{\circ} \mathrm{C}$. 


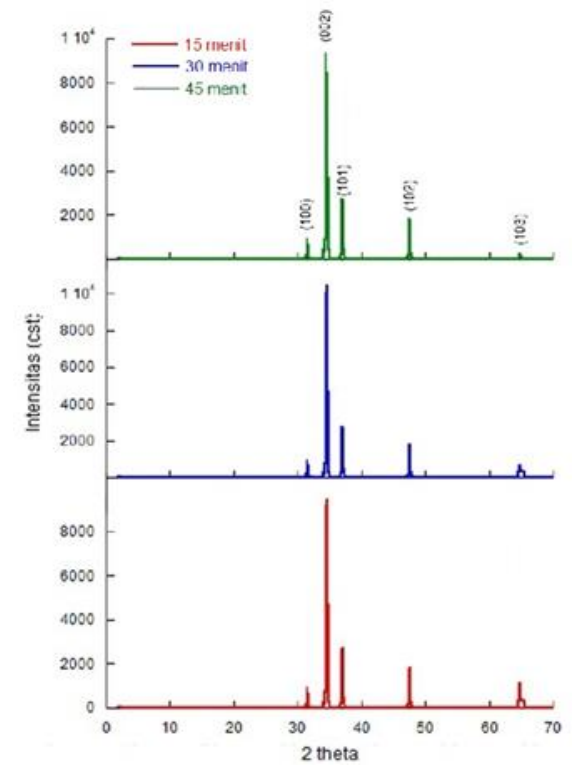

Gambar 5. Spektrum XRD Film Tipis ZnO

dengan variasi waktu tahan

Pola difraksi sinar-X Film tipis $\mathrm{ZnO}$ yang disintesis dengan pelarut isopropanol dengan suhu pre-heating $300^{\circ} \mathrm{C}$ dan suhu post-heating $550^{\circ} \mathrm{C}$ pada gambar 4.5. sistem kristal pada sampel dapat diindentifikasi dengan menggunakan free software Match! memperlihatkan kristal pelarut isopropanol mempunyai bidang-bidang (100), (002), dan (101). Untuk kristal ZnO puncak pertumbuhan terorientasi pada bidang (100) berbentuk hexagonal pada waktu tahan 15 menit dengan parameter kisi $\mathrm{a}=\mathrm{b}=5,7411 \AA$ dan $\mathrm{c}=7,044 \AA$. Untuk kristal $\mathrm{ZnO}$ puncak pertumbuhan terorientasi pada bidang (002) berbentuk hexagonal pada waktu tahan 30 menit dengan parameter kisi $\mathrm{a}=\mathrm{b}=2,9606 \AA$ dan $\mathrm{c}=7,2592 \AA$, Untuk kristal $\mathrm{ZnO}$ puncak pertumbuhan terorientasi pada bidang (101) berbentuk hexagonal pada waktu tahan 45 menit dengan parameter kisi $\mathrm{a}=\mathrm{b}=5,7812 \AA$ dan $\mathrm{c}=7,0823 \AA$.

Pada perbandingan pola XRD Gambar 4.6. sampel yang dikalsinasi dengan waktu tahan (a) 15 menit memiliki 3 puncak tertinggi yang menunjukkan fase kristal $\mathrm{ZnO}$ dengan intensitas tertentu, dari ketiga puncak tersebut intensitas tertinggi berada pada sudut $34,64^{\circ}$ dengan intensitas sebesar $9424 \mathrm{cst}$, tetapi saat waktu tahan dinaikkan menjadi (b) 30 menit fasa kristal $\mathrm{ZnO}$ yang terbentuk mengalami kenaikan intensitas sebesar 1000 cst sehingga bertambah menjadi 10424 cst dan disertai pergeseran sudut 2 theta sebesar $0,09^{\circ}$ kearah kiri menjadi $34,5^{\circ}$.
Pada saat waktu tahan (c) 45 menit terlihat intensitas pada puncak tertinggi mengalami kenaikan sebesar 1825 cst sehingga berubah menjadi 12249 cst dengan sudut 2 theta 34,44 atau bergeser $0,11^{\circ}$ kearah kiri dibanding sampel yang dikalsinasi dengan waktu tahan 30 menit.

Hal ini disebabkan karena dalam proses pemanasan, semakin tinggi waktu tahan pemanasan, puncak kristal $\mathrm{ZnO}$ semakin tinggi, karena semakin tinggi waktu tahan pemanasan, energi yang diperoleh atom-atom untuk membentuk bidang kristal semakin tinggi pula, sehingga ia memiliki kemampuan untuk menyusun diri dalam bidang-bidang tertentu. Berarti waktu tahan pemanasan mempengaruhi nilai intensitas kristal film tipis $\mathrm{ZnO}$.

\section{Ukuran Kristal Film Tipis ZnO}

Tabel 1. Ukuran Kristal ZnO

\begin{tabular}{|c|c|c|c|c|}
\hline \multirow{2}{*}{$\begin{array}{l}\text { Waktu } \\
\text { Tahan }\end{array}$} & \multirow[t]{2}{*}{ Fase } & \multicolumn{2}{|c|}{ Peak } & \multirow{2}{*}{$\begin{array}{c}\text { Ukuran } \\
\text { Kristal } \\
(\mathrm{nm})\end{array}$} \\
\hline & & $2 \theta$ (degree) & FWHM) & \\
\hline $\begin{array}{c}15 \\
\text { menit }\end{array}$ & $\mathrm{ZnO}$ & 34,6433 & 0,0773 & 96,76 \\
\hline $\begin{array}{c}30 \\
\text { menit }\end{array}$ & $\mathrm{ZnO}$ & 34,5481 & 0,0691 & 81,71 \\
\hline $\begin{array}{c}45 \\
\text { menit }\end{array}$ & $\mathrm{ZnO}$ & 34,4434 & 0,0623 & 135,8 \\
\hline
\end{tabular}

Ukuran kristal film tipis dapat diperoleh dengan menggunakan persamaan 3.1. Berdasarkan Tabel 4.1. terlihat ukuran kristal film tipis $\mathrm{ZnO}$ dipengaruhi oleh waktu tahan kalsinasi, hal ini disebabkan karena dalam proses pemanasan, semakin tinggi waktu tahan pemanasan, maka ukuran kristal semakin besar, karena semakin tinggi waktu tahan pemanasan, maka atom-atom pada butir-butir yang lebih kecil mendapat driving force yang cukup untuk berdifusi butir baru yang lebih besar. Berdasarkan nilai FWHM menunjukkan perubahan nilai yang berbeda untuk masingmasing variasi waktu tahan kalsinai. Terlihat dari nilai FWHM ZnO pada waktu tahan 15 menit memiliki nilai sebesar 0,0773 , waktu tahan kalsinasi 30 menit memiliki nilai 0,0691, sedangkan waktu tahan kalsinasi 45 menit memiliki nilai FWHM sebesar 0,0623. Perbedaan nilai FWHM mengindikasikan 
terjadinya perbedaan ukuran kristal pada $\mathrm{ZnO}$ hasil kalsinasi dengan variasi waktu tahan kalsinasi.

\section{Morfologi Film Tipis ZnO}

Film tipis $\mathrm{ZnO}$ disentesis melalui proses sol-gel dengan teknik deposisi spin coating dan pencampuran refluks. Film tipis dipanaskan pada suhu pre-heating $300^{\circ} \mathrm{C}$ selama 5 jam dan post-heating suhu yang tetap $550^{\circ} \mathrm{C}$ dengan waktu tahan yang berbeda-beda selama 5 jam. Pengujian SEM ini digunakan untuk meneliti morfologi dari suatu material. Pada penelitian ini menunjukkan hasil SEM dari sampel lapisan Zinc Oxide $(\mathrm{ZnO})$ dengan variasi waktu tahan kalsinasi 15, 30 dan 45 menit.
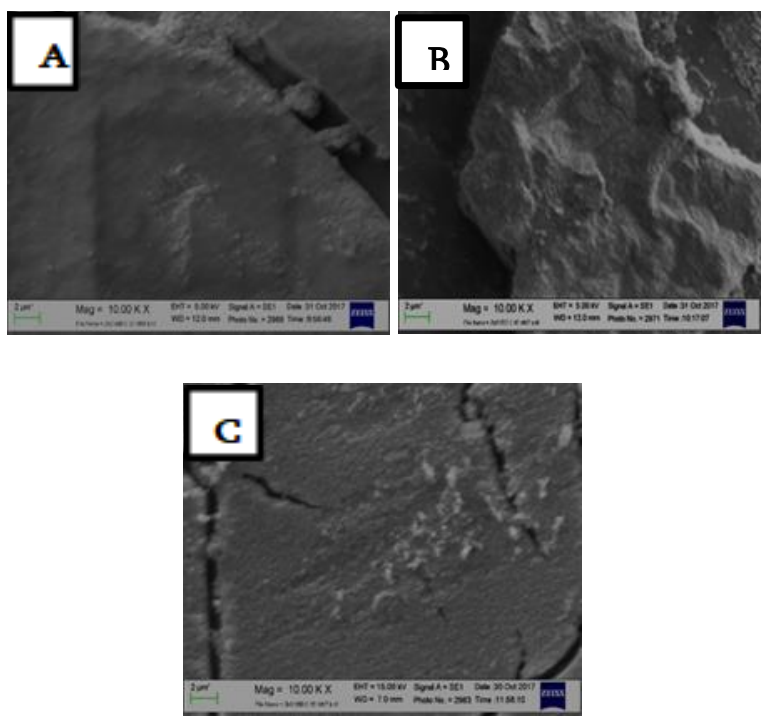

Gambar 6. Hasil SEM lapisan ZnO pada (A) $550^{\circ} \mathrm{C}$ waktu tahan 15 menit (B) $550^{\circ} \mathrm{C}$ waktu tahan 30 menit dan $(\mathrm{C}) 550^{\circ} \mathrm{C}$ waktu tahan 45

Dari Gambar 6. dengan suhu yang tetap divariasikan dengan waktu tahan yang berbeda memperlihatkan morfologi permukaan film tipis yang di post-heating pada suhu $550^{\circ} \mathrm{C}$ selama 5 jam dengan waktu tahan yang berbeda. Pada gambar 6. A distribusi butiran-butiran kristalit terlihat butiran permukaan yang kasar tidak seragam. Pada gambar 6. B hampir seragam dan kompak, dan atom-atom butir terlihat kecil karena mendapat driving force yang cukup untuk berdifusi membentuk butir baru yang lebih besar. Akibat difusi antar butir akan terbentuk necking yang mengakibatkan mengecilnya perbatasan antar butir dan porositas sehigga permukaan film tipis terlihat menjadi lebih halus. Gambar 6. C memperlihatkan distribusi butiran-butiran kristalit terlihat hampir tidak seragam dan lebih besar dibandingkan dengan butiran-butiran kristalit. Ukuran butiran atau kristalit sulit ditentukan dari hasil foto SEM karena tidak tampak batas-batas butir yang jelas serta ketidakseragaman butirannya.

\section{Pengujian UV-VIS}

Larutan dye yang di buat dari ekstrak daging buah naga merah yang dapat menyerap dan meneruskan spektrum cahaya tampak. Zat warna ini berfungsi sebagai dye sensitizer. Proses pembuatannya dengan cara di blender dan kemudian di tambahkan air sebanyak 300 $\mathrm{ml}$ dan kemudian dipanaskan sampai volumenya menjadi $100 \mathrm{ml}$ lalu disaring. Pemilihan buah naga merah ini dikarenakan memiliki kandungan antosianin yang tinggi, yang dapat dimanfaatkan sebagai absorbansi foton cahaya matahari. Pengujian UV-VIS bertujuan untuk mengetahui panjang gelombang $(\lambda)$ dan nilai absorbansi (A) dari suatu larutan, dengan cara menembakkan sinar ultraviolet (UV) pada larutan. Berikut adalah hasil ekstraksi larutan dye dari buah naga merah.

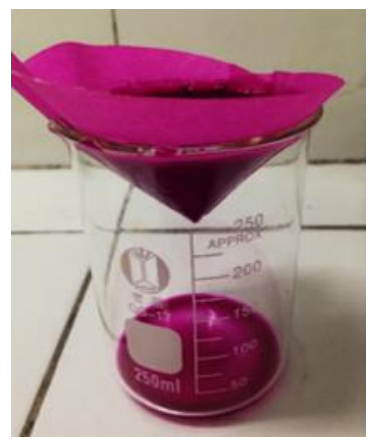

Gambar 7. Hasil ekstraksi larutan dye daging buah naga merah

Setelah pengujian, maka dihasilkan sebuah tabel yang menunjukkan panjang gelombang dan nilai absorbansinya. Grafik yang dihasilkan seperti yang ditampilkan pada Gambar 8. di bawah ini. 


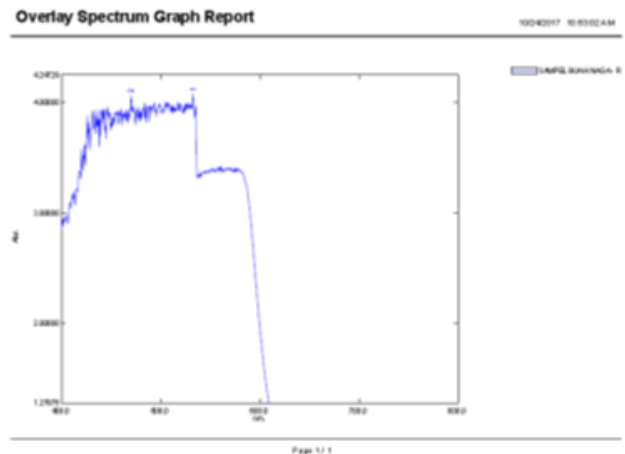

Gambar 8. Grafik Panjang Gelombang Dan Absorbansi Buah Naga Merah

Tabel 2. Hasil Pengujian Absorbansi Larutan DSSC

Dari hasil pengujian UV-VIS di atas, dapat kita ketahui bahwa nilai absorbansi daging buah naga merah adalah 3.992, sedangkan nilai panjang gelombangnya adalah $533 \mathrm{~nm}$. Hasilnya mendekati seperti yang dilakukan Nadeak, dkk (2012) mengekstrak daging buah naga merah dengan nilai panjang $538 \mathrm{~nm}$ dan absorbansi 3.300 .

Nilai absorbansi pada daging buah naga merah yang tinggi ini menunjukkan tingginya konsentrasi larutan dye dalam menyerap radiasi energi yang diberikan. Dalam penelitian ini, tentunya nilai absorbansi yang tinggi ini dapat semakin banyak menyerap foton sinar matahari. Artinya, semakin banyak pula foton yangbisa dieksitasi untuk dikonversikan oleh sel surya menjadi energi menjadi energi listrik.

Nilai absorbansi yang dihasilkan daging buah naga merah ini cukup tinggi bila di bandingkan dengan penelitian sebelumnya seperti Maddu mengekstrak daun kol merah yang menghasilkan panjang gelombang sebesar $530 \mathrm{~nm}$ dan Pancaningtyas yang mengekstrak buah manggis juga menghasilkan $530 \mathrm{~nm}$, bahkan lebih baik bila dibandingkan Chang, dkk (2010) yang mengekstrak daun bayam dan buah ipomea dengan nilai panjang gelombang $437 \mathrm{~nm}$ dan $410 \mathrm{~nm}$ secara berturut-turut juga Hardeli, dkk (2014) yang mengekstrak kulit buah naga dengan nilai panjang gelombang $532 \mathrm{~nm}$.

Setelah mengetahui panjang gelombang dan nilai absorbansinya tahap selanjutnya adalah proses perendaman film tipis pada larutan ekstrak dye daging buah naga merah. Pada elektrode dilapisi layer oksida nanopartikel yang dilapisi oleh molekul dye (zat pewarna) sensitisasi. Molekul dye berfungsi sebagai penangkap foton cahaya, sedangkan nanopartikel semikonduktor menyerap dan meneruskan foton menjadi elektron.

\section{Pengujian Nilai Tegangan}

Hasil pengujian voltase pada prototip sel surya dengan variasi waktu tahan kalsinasi dapat dilihat pada Tabel 4.3. berikut.

Tabel 3. Hasil Pengujian Tegangan DSSC Buah Naga Merah Selama 10 Hari

\begin{tabular}{|c|c|c|c|c|c|c|c|c|c|c|}
\hline No & \multicolumn{3}{|c|}{$\begin{array}{l}\text { Ekstrak } \\
\text { Larutan }\end{array}$} & \multicolumn{4}{|c|}{$\begin{array}{c}\text { Panjang } \\
\text { Gelombang } \\
(\mathrm{nm})\end{array}$} & \multicolumn{3}{|c|}{$\begin{array}{c}\text { Nilai } \\
\text { Absorbansi }\end{array}$} \\
\hline 1 & \multicolumn{3}{|c|}{$\begin{array}{l}\text { Daging buah } \\
\text { naga merah }\end{array}$} & \multicolumn{4}{|c|}{533} & \multicolumn{3}{|c|}{3.992} \\
\hline \multirow{2}{*}{$\begin{array}{c}\text { Waktn } \\
\text { Tahan } \\
\text { (menit } \\
\text { ) }\end{array}$} & \multicolumn{10}{|c|}{ Nilai tegangan per hari $(\mathrm{mV})$ dengan suhu $550^{\circ} \mathrm{C}$} \\
\hline & 1 & 2 & 3 & 4 & 5 & 6 & 7 & 8 & 9 & 10 \\
\hline \multirow[t]{2}{*}{15} & 548 & 703 & 620 & 593 & 587 & 555 & 514 & 494 & 478 & 452 \\
\hline & 754 & 1114 & 778 & 739 & 703 & 667 & 664 & 611 & 554 & 533 \\
\hline 30 & 648 & 736 & 635 & 617 & 599 & 569 & 543 & 512 & 497 & 471 \\
\hline
\end{tabular}

Dari Tabel 4.3. diketahui nilai voltase pada spesimen dari masing-masing kalsinasi pada hari pertama nilai voltasenya cukup tinggi, sedangkan pada hari kedua mengalami kenaikkan yang sebesar $980 \mathrm{mV}$ begitu juga dengan waktu tahan 15 menit dan 45 yaitu dengan nilai masing-masing $703 \mathrm{mV}$ dan 726 $\mathrm{mV}$. Namun setelah hari kedua DSSC menit ini mengalami penurunan hingga hari terakhir yaitu pada hari kesepuluh. Hal ini disebabkan karena menguapnya $d y e$ dari buah naga merah dan acetonitrile akibat selama sepuluh hari terkena sinar matahari. Sehingga menurunkan pula kemampuan dari DSSC tersebut. Dan penurunan nilai voltase itu sendiri rata-rata mengalami penurunan sebesar $30-40 \mathrm{mV} / \mathrm{hari}$. Hasil paling optimal nilai dari voltase DSSC ini yakni pada hari kedua karena menyerapnya yang sempurna antara counter elektroda dengan dye dari daging buah naga merah.

Pada hari pertama pengujian voltase menunjukkan nilai yang tidak begitu tinggi 
untuk masing-masing waktu tahan. Hal ini disebabkan pada hari pertama yaitu prototipe DSSC setelah selesai di-assembling langsung diuji sehingga larutan dye dan larutan elektrolit yang masih belum menyerap sempurna pada lapisan Zink Oksida ( $\mathrm{ZnO})$, maka membuat kinerja solar cell, terutama dalam absorbsi foton cahaya masih kurang maksimal dan membutuhkan waktu yang lebih lama lagi untuk pengeringan, agar dye dan elektrolit dapat menyerap sempurna sehingga dapat bekerja secara maksimal.

Hal ini serupa dengan penelitian yang dilakukan oleh Nafi'dkk (2013) bahwa pada hari pertama menunjukkan nilai voltase yang lebih rendah dibandingkan hari kedua. Dari hasil penelitian Nadeak, dkk (2012) menyimpulkan bahwa semakin tinggi temeperatur kalsinasi yang diberikan, maka semakin meningkat nilai voltasenya. Nilai voltase tertinggi dicapai pada variasi temeperatur $500^{\circ} \mathrm{C}$ dalam waktu tahan kalsinasi 30 menit yaiutu sebesar $723 \mathrm{mV}$.

Pada penelitian kali ini waktu tahan yang dinaikkan dan temperatur tetap menghasilkan fakta bahwa nilai voltase tertinggi yang dicapai sebesar $980 \mathrm{mV}$ dengan variasi waktu tahan 30 menit. Dari fenomena penelitian ini bisa disimpulkan adanya temperatur optimum dimana DSSC dapat memberikan tegangan listrik dengan maksimal, dalam hal ini pada temperatur $550^{\circ} \mathrm{C}$ waktu tahan 30 menit. Karena pada variasi temperatur yang tetap degan waktu tahan 15 menit dan 45 menit voltase yang dihasilkan menurun.

Hail pengujian voltase dari DSSC dengan ekstrak buah naga merah, terjadi kecenderungan penurunan voltase dari ke-2 dan terjadi penurunan serta nilai voltase yang bervariasi hingga hari ke 10. Berdasarkan penelitian sebelumnya (Pacaningtyas, dkk, 2008), hal tersebut disebabkan karena tingkat difusi I- yang rendah melalui matriks DSSC, dan terjadi penguapan yang mudah dari elektrolit cair. Selain itu iodine yang berperan sebagai komponen untuk terjadinya reaksi redoks dalam larutan eletrolit, mempunyai stabilitas rendah karena mudah teroksidasi oleh udara. Proses oksidasi ini semakin dipercepat karena prinsip kerja sel surya yaitu dibawah sinar matahari. Setelah selama sepuluh hari dilakukan pengujian nilai tegangan pada sampel film tipis 15, 30 dan 45 menit diperoleh nilai rata-rata pada setiap sampel film tipis yang dapat dilihat dari Tabel 4 . berikut.

Tabel 4. Nilai Rata-Rata Tegangan (mV) Selama 10 Hari

Dari Tabel 4. dapat dilihat bahwa nilai rata-rata tegangan yang diperoleh dari sampel film dengan waktu tahan 15 menit sebesar 554.4 $\mathrm{mV}$ mengalami kenaikan nilai rata-rata pada sampel film tipis dengan waktu tahan 30 menit sebesar $711.7 \mathrm{mV}$ lalu mengalami penurunan pada sampel film tipis 45 menit yaitu $582.7 \mathrm{mV}$. Perbandingannya dapat dilihat dari Gambar 4.9. berikut.

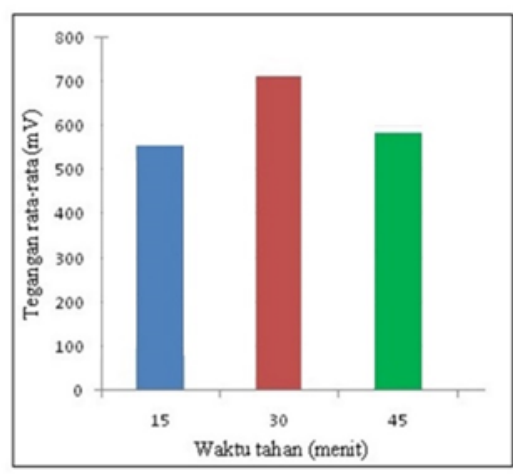

Gambar 9. Grafik Perbandingan Nilai Rata-Rata Tegangan Selama 10 Hari Dengan Waktu Tahan 15, 30 dan 45 Menit

Faktor lainnya yang mungkin berpengaruh pada berkurangnya stabilitas dan performa prototipe DSSC yaitu dari dye yang merupakan larutan organik, yang bersifat kurang stabil dan mudah rusak. Selain itu pula, pelapisan semikonduktor $\mathrm{ZnO}$ ke substrat kaca konduktif FTO yang kurang sempurna (terlalu tebal atau terlalu tipis) juga mempengaruhi hasil dari pengujian listrik ini. Lapisan $\mathrm{ZnO}$ yang rapuh dan mudah rontok dari substrat kaca konduktif FTO yang kemungkinan mengalami penurunan serta kenaikan yang bervariasi karena dipanaskan hingga temperatur tinggi, juga merupakan faktor yang mempengaruhi penurunan voltase DSSC.

\section{Pengujian Nilai Arus}

Tabel 5. Hasil Pengujian Nilai Arus DSSC Buah Naga Merah Selama 10 Hari 


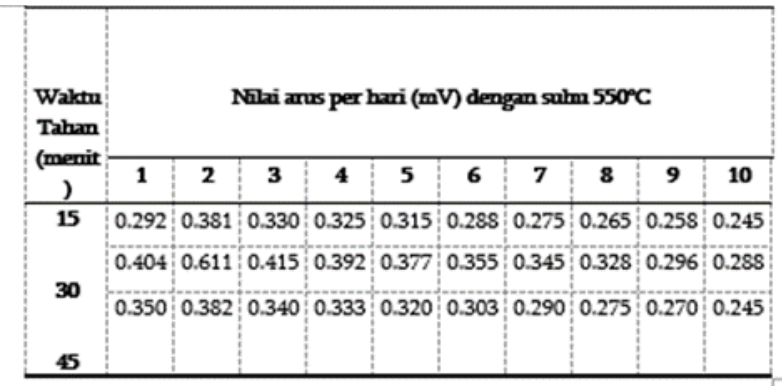

Berdasarkan Tabel 4.5. menunjukkan hal yang serupa dengan trend dari pengkuran voltase, dimana densitas arus mengalami kenaikan pada waktu tahan 30 menit, dan menurun pada 45 menit. Setelah selama sepuluh hari dilakukan pengujian nilai arus pada sampel film tipis 15, 30 dan 45 menit diperoleh nilai rata-rata pada setiap sampel film tipis yang dapat dilihat dari Tabel 4.5. berikut.

Tabel 6. Nilai Rata-Rata Arus $\left(\mathrm{mAcm}^{2}\right)$ Selama 10 Hari

Dari Tabel 4.6. dapat dilihat bahwa nilai rata-rata arus yang diperoleh dari sampel film dengan waktu tahan 15 menit sebesar 0.297 $\mathrm{mAcm}^{2}$ mengalami kenaikan nilai rata-rata pada sampel film tipis dengan waktu tahan 30 menit sebesar $711.7 \mathrm{mAcm}^{2}$ lalu mengalami penurunan pada sampel film tipis 45 menit yaitu 582.7 $\mathrm{mAcm}^{2}$. Perbandingannya dapat dilihat dari Gambar 10. berikut.

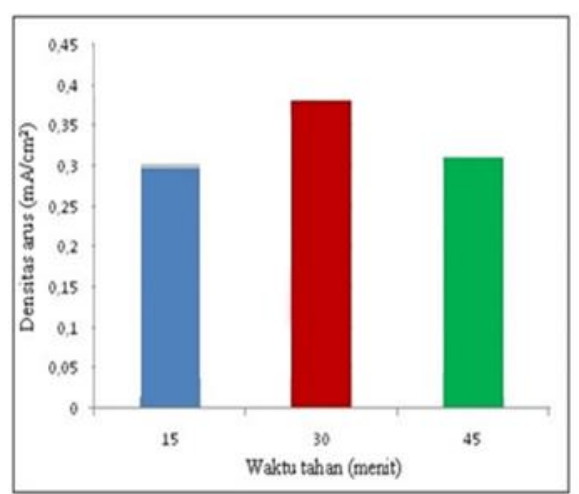

Gambar 10. Grafik Perbandingan Nilai Rata-Rata Arus Selama 10 Hari Dengan Waktu Tahan 15, 30 dan 45 Menit

Secara umum dapat dilihat pada gambar bahwa nilai rata-rata arus dari DSSC ekstrak buah naga merah terlihat fluktuatif. Namun dapat dilihat dengan seksama bahwa nilai nilai rata-rata arus memiliki nilai terendah pada hari pertama, pada setiap variasi. Sedangkan memiliki nilai tertinggi pada hari ke-2 pada setiap variasi, dan terus mengalami penurunan nilai seiring bertambahnya hari.

Densitas arus yang dihasilkan dari DSSC ekstrak buah naga merah masih sangat rendah, yaitu dalam kisaran microampere $\left(\mathrm{mA} / \mathrm{cm}^{2}\right)$. Pada penelitian ini, yang memiliki nilai densitas arus tertinggi yaitu prototipe dengan variasi waktu tahan $550^{\circ} \mathrm{C}$ dengan waktu tahan kalsinasi 30 menit, yaitu senilai $0.600 \mathrm{~mA} / \mathrm{cm}^{2}$. Sedangkan, pada penelitian sebelumnya (Nadeak, dkk 2012) mendapatkan densitas arus tertinggi sebesar $0.307 \mathrm{~mA} / \mathrm{cm}^{2}$ dengan menggunakan $d y e$ dari ekstrak buah naga dan variasi temperatur $550^{\circ} \mathrm{C}$ dengan waktu tahan kalsinasi 60 menit. Rendahnya nilai densitas arus ini dikarenakan hambatan yang dilalui oleh elektron dalam melewati lapisan tiap lapisan dari DSSC ekstrak naga merah masih sangat besar. Selain itu, juga bisa disebabkan karena

\begin{tabular}{cc}
$\begin{array}{c}\text { Waktu Tahan } \\
\text { (menit) }\end{array}$ & $\begin{array}{c}\text { Nilai Rata-Rata Tegangan (mV) } \\
\text { Selama 10 Hari }\end{array}$ \\
\hline 15 & 554.4 \\
30 & 711.7 \\
45 & 582.7 \\
\hline
\end{tabular}

transfer elektron di dalam lapisan $\mathrm{ZnO}$ (fotoelektroda) masih belum maksimal.

Nilai densitas arus yang cenderung fluktuatif atau naik turun ini bisa disebabkan karena stabilitas komponen DSSC yang kurang optimal, dikarenakan larutan dye dan larutan elektrolit berupa zat cair yang mudah menguap, serta dye buah naga merah yang mulai terkikis semakin bertambahnya hari. Larutan dye yang terbuat dari buah naga merah sangat rentan rusak karena terbuat dari bahan organik.

\section{Efisiensi Dye Sensitized Solar Cell Naga Merah}

Pada masing-masing variasi DSSC naga merah, diperoleh nilai voltase dan densitas arus terbesar yang digunakan untuk menghitung nilai efisiensi DSSC naga merah. Hasil perhitungannya ditampilkan pada tabel 4.5 dan 4.6 di bawah ini.

Tabel 7. Nilai Kelistrikan Maksimum DSSC Naga Merah

\begin{tabular}{ccccc}
\hline $\begin{array}{c}\text { Temp } \\
\left({ }^{\circ} \mathrm{C}\right)\end{array}$ & $\begin{array}{c}\text { Waktu } \\
\text { tahan } \\
(\mathrm{menit})\end{array}$ & $\begin{array}{c}\mathrm{V} \max \\
(\mathrm{mV})\end{array}$ & $\begin{array}{c}\mathrm{I} \max \\
(\mathrm{mA} / \mathrm{c} \\
\left.\mathrm{m}^{2}\right)\end{array}$ & $\begin{array}{c}\mathrm{P} \max \\
\left(\mathrm{mW} / \mathrm{cm}^{2}\right)\end{array}$ \\
\hline 550 & 15 & 703 & 0.381 & $267.84 \times 10^{-3}$ \\
550 & 30 & 1114 & 0.590 & $657.26 \times 10^{-3}$
\end{tabular}


Tabel 8. Efisiensi Kelistrikan DSSC Naga Merah

\begin{tabular}{|c|c|c|c|c|c|}
\hline $\begin{array}{l}\text { Temp } \\
\left({ }^{\circ} \mathrm{C}\right)\end{array}$ & $\begin{array}{c}\text { Waktu } \\
\text { tahan } \\
\text { (menit) }\end{array}$ & $\begin{array}{c}\text { Ukuran } \\
\text { kristal } \\
\\
(\mu \mathrm{m})\end{array}$ & $\begin{array}{c}\mathrm{P} \max \\
\left(\mathrm{mW} / \mathrm{cm}^{2}\right)\end{array}$ & $\begin{array}{c}\text { P input } \\
(\mathrm{mW} / \mathrm{cm} \\
2)\end{array}$ & $\begin{array}{c}\eta \\
(\%)\end{array}$ \\
\hline 550 & 15 & 96.76 & $\begin{array}{c}267.84 \times 10^{-} \\
3\end{array}$ & 450 & 0.05952 \\
\hline 550 & 30 & 81.71 & $\underset{3}{657.65 \times 10^{-}}$ & 450 & 0.14605 \\
\hline 550 & 45 & 135.8 & $\underset{3}{281.15 \times 10^{-}}$ & 450 & 0.06247 \\
\hline
\end{tabular}

Hasil penelitian Tabel 7. membuktikan bahwa semakin meningkat pada variasi waktu tahan kalsinasi 15 menit ke 30 menit dan menurun pada 45 menit yang secara tidak langsung membuktikan bahwa adanya waktu tahan optimum yang bisa digunakan dalam proses ini yaitu waktu tahan 30 menit.

Nilai efisiensi terbesar diperoleh pada DSSC dengan variasi waktu tahan 30 menit dengan suhu $550^{\circ} \mathrm{C}$ yaitu $0.1512 \%$. Nilai tersebut menunjukkan bahwa efisiensi prototipe DSSC masih rendah dan belum bisa maksimal dalam menyerap daya matahari untuk dikonversikan menjadi energi listrik. Namun, penelitian kali ini menghasilkan nilai efisiensi yang lebih tinggi dibandingkan dengan penelitian sebelumnya (Akbar, 2013) yaitu sebesar 0.14972 .

Pada penelitian pembuatan Dye Sensitized Solar Cell yang menggunakan dye dari buah naga merah dengan bahan semikonduktor berupa $\mathrm{ZnO}$ dapat disimpulkan bahwa prototipe dalam mengkonversi energi cahaya matahari menjadi energi listrik ini setelah diuji morfologinya menurut Gambar 4.7. belum menghasilkan pori dan untuk mengahsilkan pori dengan energi $30 \mathrm{kV}$ dari SEM dan perbesarannya 10.000 kali paling kecil untuk optik. Lalu dari pengujian UV-VIS pada Gambar 4.9. spektrum yang dihasilkan belum terlihat pembentukan puncak dan lebar puncaknya. Faktor selanjutnya yang mempengaruhi adalah larutan elektrolit belum diuji kebenarannya baik atau tidak untuk digunakan dalam penelitian ini. Dari semua faktor tersebut menyatakan bahwa yang dihasilkan pada penelitian ini belum bisa digunakan karena menghasilkan nilai efisiensi sangat kecil yaitu $0.06247 \%$.

\section{Kesimpulan \\ KESIMPULAN DAN SARAN}

1. Dye Sensitized Solar Cell (DSSC) dapat difabrikasikan menggunakan semikonduktor film tipis $\mathrm{ZnO}$ dan dye dari ekstrak buah naga merah.

2. Nilai absorbansi dan panjang gelombang ekstrak buah naga merah yaitu 3.992 dan $533 \mathrm{~nm}$. DSSC dapat mengkonversi energi cahaya matahari menjadi energi listrik.

3. Ukuran kristal film tipis $\mathrm{ZnO}$ dengan variasi waktu tahan 15,30 dan 45 menit adalah 96.76, 81.71 dan $135.8 \mathrm{~nm}$.

4. Hasil morfologi film tipis $\mathrm{ZnO}$ pada uji SEM menunjukkan bahwa semakin ditingkatkannya waktu tahan kalsinasi makan butiran buitran kristalit semakin halus tapi tidak merata. Ukuran butiran atau kristalit sulit ditentukan dari hasil foto SEM karena tidak tampak batasbatas butir yang jelas serta ketidakseragaman butirannya.

5. Nilai efisiensi pada variasi waktu tahan 15, 30 dan 45 menit sebesar $0.05952 \%$, $0.14605 \%$ dan $0.06247 \%$.

Saran

1. Sebaiknya pada penelitian selanjutnya $\mathrm{ZnO}$ yang digunakan berukuran nanopartikel.

2. Mengganti dye dengan panjang gelombang dan absorbansi yang lebih baik lagi.

3. Mengganti larutan elektrolit gel atau padatan, agar tidak mudah menguap sehingga arus yang dihasilkan lebih besar dan stabil.

4. Menggunakan metode lain dalam penyusunan sandwich DSSC (tidak menggunakan klip binder) agar elektrolit yang diteteskan tidak mudah keluar sehingga elektrolit tidak cepat habis.

5. Film tipis $\mathrm{ZnO}$ dengan suhu pre-heating $300^{\circ} \mathrm{C}$ perlu dilakukan pengujian karakterisasi spektrum XRD. 


\section{DAFTAR PUSTAKA}

Adityawan, Eki. (2010). Studi Karakterisasi Pencatuan Solar Cell Terhadap Kapasitas Sistem Penyimpanan Energi Baterai. Depok: Universitas Indonesia.

Adolf Goetzberger, Chistopher Hebling, HansWerner Shock. (2003).Photovoltaic Materials, History, Status And Outlook. Materials Science Ad Engineering R 40 Page: 1-46.

Fatiatun. (2015). Pengaruh Suhu Deposisi Terhadap Sifat Fisis Film Tipis Seng Oksida Doping Galium Oksida Dengan Metode DC Magnetron Sputtering. Semarang: UNS.

Gratzel, Michael. (1998). Demonstrating Elecrtron Transfer And Nanotechnolog : A Natural Dye Sensitized Naocrystaline Energy Converter. Journal of Chemical Eduacation 75 (6), Page: 752.

Gratzel, Michael. (2003). Dye Sensitized Solar Cell. Journal Of Photochemistry And Photobiology. Vol 4, 145-153.

Handini, W., Herman. A. (2008). Performa Sel Surya Tersensitasi Zat Pewarna (DSSC) Berbasis ZnO Dengan Variasi Tingkat Pengisian Dan Besar Kristalit TiO2. Skripsi S1 Departemen Teknik Metalurgi Dan Material, Universitas Indonesia.

Hardeli. (2011). Pembuatan Prototipe Dye Sensitized Solar Cell (DSSC) Menggunakan Ubi Jalar Ungu, Wortel Dan Kunyit Sebagai Sumber Zat Warna. Padang: UNP.

Hardjadinata, S. (2010). Budi Daya Buah Naga Super Red Secara Organik, Edisi Pertama. Jakarta: Penebar Swadaya.

Jamila, B., Shu, C. E., Kharidah, M., Dzulkifly, M.A And Noraniza N, A., 2011.Physico- Chemical Characteristics Of Red Pitaya (Hylocereuspolyrhizus) Peel.Journal Of Agricultural Food Chemistry,18: 279-286.

Kao P.-C.,Chu.S.Y., Li. B.-J., Chang, H.-H., Fang Y.-C., Chang R.-C,. (2009). Low Temperature Solution-Sysnthesis Protoluminescene Properties $\mathrm{ZnO}$
Nanowires, J. Alloys Compd. 467. Page, 342-246.

Kumara, M,S,W., Prajitno, G. (2012). Studi Awal Fabrikasi Dye Sensitized Solar Cell (DSSC) Dengan Menggunakan Ekstraksi Daun Bayam (Amaranthus Hybirdus L.) Sebagai Dye Sensitizer Dengan Variasi Jarak Sumber Cahaya Pada DSSC. Surabaya: Institut Teknologi Surabaya.

Maddu, A., Zuhri, I. (2007). Penggunaan Ekstrak Antosianin Kol Merah Sebagai Fotosensitizer Pada Sel Surya Tio2 Nanokristal Tersensititasi Dye. Makara, Teknologi, Vol 11, No. 2. Hal, 78-84.

Misbachudin, C, M., Ferdy, S, R, Dan Sutresno A. (2014). Pengaruh $\mathrm{pH}$ Larutan Antosianin Strawberry dalam Prototipe Dye Sensitized Solar Cell (DSSC). Salatiga: Universitas Kristen Satya Wacana.

Nadeak, S,M,R., Susanti, D. (2012). Variasi Temperatur Dan Waktu Tahan Kalsinasi Terhadap Unjuk Kerja Semikonduktor Tio2 Sebagai Dye Sensitized Solar Cell (DSSC) Dengan Dye Dari Ekstrak Buah Naga Merah. Surabaya: Institut Teknologi Surabaya.

Nafi, M., Susanti D. (2013). Aplikasi Semikonduktor Tio2 Dengan Variasi Temperatur Dan Waktu Tahan Kalsinasi Sebagai Dye Sensitized Solar Cell (DSSC) Dengan Dye Dari Ekstrak Buah Terung Belanda (Solanum Betaceum). Surabaya: Institut Teknologi Surabaya.

Nurdin, S., (2015). Studi Sintesis Dan Karakteristik Film Tipis ZnO Dengan Metode Sol-gel Spin Coating. Disertasi. FMIPA. Sumatera Utara, Medan.

Prasatya, A,N., Susanti D. (2013). Pengaruh Temperatur Kalsinasi Pada Kaca Fto Yang Di Coating Zno Terhadap Efisiensi DSSC (Dye Sensitized Solar Cell) Yang Menggunakan Dye Dari Buah Terung Belanda (Solanum Betaceum). Surabaya: Institut Teknologi Surabaya. 
Rahman, A. (2009). Pengaruh Tingkat Kekristalan Tio2 Pada Tegangan Terbuka Sel Surya Tersensitisasi Pewarna Berbasis Zno- Tio2. Fakultas Teknik Universitas Indonesia.

Saiful, Mannan. (2015). Energi MatahariSumber Energi Alternatif Yang Effisien Handal Dan Ramah Lingkungan Di Indonesia. Semarang: Fakultas Teknik Univeristas Diponegoro.

Septina, W., D. Fajarisandi, Dan M. Aditia. (2007). Pembuatan Prototipe Solar Cell Murah Dengan Bahan OrganikInorganik (Dye Sensitized Solar Cell). Bandung: Laporan Penelitian Bidang Energi. ITB.

Smestad, G.P., \& Gratzel, M., 1998. Demostrating Electron Transfer And Nanotechnology: A Natural Dye Sensitized Nanocrystaline Energy Conventer, J.Chem. Educ.,75, 752-756.

Subodro, Rohmat. (2012). Ekstraksi Pewarna Bahan Antosianin Kulit Terong Ungu Sebagai Pewarna Alami Pada Sel Surya Dye Sensitized Solar Cell (DSSC). Surakarta: Universitas Nahdlatul Ulama.

Sugiono, (2002). Kaji Numerik Proses Di Dalam Kalsiner. Bandung: Institut Teknologi Bandung.

Suharto, (2008). Pencegahan Dan Penyembuhan Penyakit Jantung Koroner.Jakarta : Gramedia Pustaka Utama.

Widodo, S. (2010). Teknologi Sol-Gel Pada Pembuatan Nano Kristalin Metal Oksida Untuk Aplikasi Sensor Gas. Bandung: Semina Rekayasa Kimia Lipi. Wongcharee, K., Meyoo, V., Chavadej, S. (2007). Dye Sensitized Solar Cell Using Natural Dyes Extracted From Rosella And Blue Pea Flowers. Solar Energy Materials And Solar Cells 91 (2007) 566-571.

Wu, L.C., Hsu, H.W., Chen, Y.C., Chiu, C.C., Lin, Y.I. \& Ho, J.A. (2006). Antioxidant And Antiproliferative Activities Of Red Pitaya. Food Chemistry, 95: 319-327. 